\title{
Virus Transmission by Aphis gossypii Glover to Aphid-resistant and Susceptible Muskmelons
}

\author{
Albert N. Kishaba ${ }^{1}$, Steven J. Castle ${ }^{2}$, and Donald L. Coudriet ${ }^{3}$ \\ U.S. Department of Agriculture, Agricultural Research Service, Boyden Entomology Laborator, \\ University of California, Riverside, CA 92521
}

\author{
James D. McCreight ${ }^{4}$ \\ U.S. Department of Agriculture, Agricultural Research Service, U.S. Agricultural Research Station, \\ 1636 East Alisal Street, Salinas, CA 93905

\section{G. Weston Bohn ${ }^{5}$} \\ U.S. Department of Agriculture, Agricultural Research Service, Irrigated Desert Research Station, \\ 4151 Highway 86, Brawley, CA 92227
}

\begin{abstract}
Additional index words. Cucumis melo, watermelon mosaic virus, zucchini yellow mosaic virus, melon aphid, melon aphid resistance

Abstract. The spread of watermelon mosaic virus by the melon aphid (Aphis gossypii Glover) was 31\%, 74\%, and $\mathbf{7 1 \%}$ less to a melon aphid-resistant muskmelon (Cucumis melo L.) breeding line than to the susceptible recurrent parent in a field cage study. Aphid-resistant and susceptible plants served equally well as the virus source. The highest rate of infection $(\mathbf{9 7 . 9 \%})$ was noted when target plants were all melon-aphid susceptible, least $(26.7 \%)$ when the target plants were all melon-aphid resistant, and intermediate $(69.4 \%)$ when the target plants were an equal mix of aphid-resistant and susceptible plants. The number of viruliferous aphids per plant required to cause a $50 \%$ infection varied from five to 20 on susceptible controls and from 60 to possibly more than 400 on a range of melon aphidresistant populations. An $F$ family from a cross of the melon aphid-resistant AR Topmark (AR TM) with the susceptible 'PMR 45' had significantly less resistance to virus transmission than AR TM. Breeding line AR 5 (an aphid-resistant population with 'PMR 5' as the recurrent parent) had significantly greater resistance to transmission than other aphid-resistant populations.
\end{abstract}

Muskmelons are subject to several diseases caused by viruses that are transmitted in a nonpersistent manner by aphids (Dodds et al., 1983; Milne et al., 1969; Nameth et al., 1985). The melon aphid not only colonizes and causes direct feeding damage on muskmelon (Metcalf et al., 1962), but also vectors many plant viruses (Smith, 1972), including muskmelon viruses (Coudriet, 1962). Kishaba et al. (1971) reported resistance to the melon aphid in PI 371795. This discovery led to detailed studies of the mechanisms and genetic control of resistance (Bohn et al., 1972, 1973; Kennedy and Kishaba, 1977; Kennedy et al., 1975, 1978; Kishaba et al., 1971, 1976) and culminated in the release of three melon aphid-resistant breeding lines (McCreight et al., 1984).

Lecoq et al. (1979) reported resistance to cucumber mosaic virus (CMV) transmission by the melon aphid in muskmelon PI 161375. That resistance was found to be vector-specific but not virus-specific (Lecoq et al., 1980). Subsequently, Pitrat and Lecoq (1980) reported five other sources of resistance to melon aphid transmission of viruses. One of those sources was PI

Received for publication 4 Mar. 1991. Accepted for publication 10 Sept. 1991. Research performed in cooperation with Univ. of California, Riverside. We thank K. Higa and P. Murashige for their technical assistance in the early studies; C. Huszar for statistical interpretation; and G. Kennedy, G. Manglitz, and D.S. Moreno for their reviews of the manuscript. Mention of a proprietary product in this paper does not constitute endorsement of the product by the U.S. Dept. of Agriculture. The cost of publishing this paper was defrayed in part by the payment of page charges. Under postal regulations, this paper therefore must be hereby marked advertisement solely to indicate this fact.

'Research Entomologist. Present address: Crop Quality and Fruit Insects Research, 2301 S. International Blvd., Weslaco, TX 78596.

${ }^{2}$ Present address: SW Idaho Research and Extension Center, 29603 U of I Lane, Parma ID 83660-9637.

${ }^{3}$ Retired. present address: 17522 E. Grande Blvd., Fountain Hills, AZ 85268.

${ }^{4}$ Research Horticulturist.

${ }^{5}$ Retired. Present address: 1094 Klish Way, Del Mar, CA 92014.
414723, which we had derived from PI 371795 by field selection for melon aphid resistance and subsequent inbreeding.

Resistance to virus transmission was associated with the antixenosis (Kogan and Ortman, 1978) modality of melon aphid resistance in PI 161375 (Lecoq et al., 1980). Pitrat and Lecoq (1982) reported that plants of PI 414723 that were not accepted by aphids also exhibited antibiosis. Because the same gene governs nonacceptance and resistance to virus transmission, they postulated that the same gene also governs antibiosis.

Moyer et al. (1985) reported resistance to virus multiplication of watermelon mosaic virus (WMV = WMV 2; Purcifull et al., 1984) in a melon aphid-resistant inbred line from PI 371795. One of our melon aphid-resistant Topmark breeding lines, derived from a cross with a different inbred from PI 371795, lacked this resistance. Using the same lines, Gray et al. (1986) found combinations of plant resistance to aphid-virus multiplication and to aphid-virus transmission to be effective in reducing incidence of WMV in spring plantings in North Carolina. Romanow et al. (1986) applied the concept of the probability of a single-aphid transmission (Swallow, 1985) and partitioned the causes of the reduced virus infection into resistance to virus multiplication, melon aphid resistance, and resistance to virus transmission by the melon aphid.

Concurrent with the research in France and North Carolina, we examined possible effects of our melon aphid-resistant lines on virus spread. We reported increased alate melon aphid movement on melon aphid-resistant lines (Kennedy and Kishaba, 1977). This movement, an effect of antixenosis (Kogan and Ortman, 1978), and the possible effects of antibiosis alerted us to the

Abbreviations: ANOVA, analysis of variance; AR HBJ, AR Hale's Best Jumbo; AR TM, AR Topmark; AR 45, aphid-resistant 'PMR 45'; CMV, cucumber mosaic virus; HBJ, 'Hale's Best Jumbo'; $\mathrm{EN}_{50}, 50 \%$ infection; WMV, watermelon mosaic virus; ZYMV, zucchini yellow mosaic virus. 
possibility that melon aphid resistance may increase virus spread (Kennedy, 1976).

Our objective was to develop an expedient method to evaluate and compare resistance to virus transmission among melon aphidresistant breeding lines. We report here experiments on the spread of nonpersistent viruses in melon aphid-resistant breeding lines that are tolerant to melon aphid feeding (Bohn et al., 1973) and antibiotic to melon aphid reproduction (Kishaba et al., 1976). We also report differences in resistance to WMV and zucchini yellow mosaic virus (ZYMV) transmission by the melon aphid among several melon aphid-resistant populations.

\section{Materials and Methods}

\section{General}

Two series of field cage tests were conducted to compare the effect of melon aphid resistance on virus transmission by many melon aphids to melon aphid-resistant and susceptible muskmelon. Three series of greenhouse tests were established to compare resistance to virus transmission among diverse melon aphid-resistant muskmelon genotypes. Resistance to virus transmission was measured as the percentage of infected plants based on visual symptoms.

Test muskmelon seeds were germinated between moistened paper towels or in moist vermiculite in petri dishes in an incubator (30C day/24C night). Upon germination, they were transplanted into pots of different sizes as specified for each test. Steam-sterilized soil mix (1 sphagnum : 4 soil : 5 silt : 5 sand : 5 vermiculite) served as the support medium. Plants were watered daily with Hewitt solution, as modified by Ward (1973), at one-fifth of the micronutrient concentration and maintained in an insect-free, smog-filtered greenhouse.

The melon aphid colony used in the field cage and greenhouse transmission tests was maintained in isolation for many years (Kishaba et al., 1971) on muskmelon 'PMR 45'. The WMV culture used in these tests was purified and indexed on differential hosts (Demski, 1968; Milne et al., 1969; Webb, 1965; Webb and Scott, 1965). The ZYMV culture used was as described by Nameth et al. (1985).

For field cage studies, eight plants of each line were inoculated with WMV by mass infestation with viruliferous melon aphids when plants reached the late one-leaf or early two-leaf stage of development. Nine days after inoculation, when symptoms were obvious, six plants of each line were selected for use as virus source plants. For the greenhouse tests, 'PMR 45' plants 3 to 5 weeks postinoculation were used as virus source plants.

About 1000 aviruliferous melon aphids for greenhouse transmission studies were brushed from glabrous 'PMR 45' (Foster, 1963) test culture plants into $15 \times 100-\mathrm{mm}$ plastic petri dishes lined with moist filter paper; the aphids were then starved for $\approx 2 \mathrm{~h}$. The required number of petri dishes with aphids was prepared at the same time. WMV- or ZYMV-infected leaves were cut into $\approx 1-\mathrm{cm}^{2}$ pieces and introduced into a petri dish containing the starving melon aphids. After an acquisition period of $\approx 1 \mathrm{~h}$, when a majority of the aphids had settled on the leaf squares, leaf squares with a known number of viruliferous melon aphids were transferred onto each of the melon test plants, which were caged individually or in sets of four. Viruliferous melon aphids fed for 12 to $24 \mathrm{~h}$ and then were killed with 2,2dichlorovinyl dimethyl phosphate (dichlorvos) strips.

Test plants were moved a few days later into an incubation greenhouse where cages were removed and the greenhouse was fumigated with dichlorvos (Florafume formulation). Plants were examined for virus symptoms every 3rd day for 21 days; then the number of target plants with virus symptoms was recorded and the test was concluded. For the field cage studies, a different procedure was followed and will be described along with the tests.

\section{Field cage virus transmission tests}

A comparative study of the effect of melon aphid resistance on spread of WMV was conducted with melon aphid-susceptible 'Hales Best Jumbo' (HBJ) and melon aphid-resistant AR Hale's Best Jumbo (AR HBJ), a melon aphid-resistant breeding line derived from HBJ and PI 371795 (McCreight et al., 1984).

The field cages were $3.4 \mathrm{~m}$ wide $\mathrm{x} 7 \mathrm{~m}$ long $\mathbf{x} 1.5 \mathrm{~m}$ high and covered with 32-mesh (0.54 x 0.54-mm openings) Saran screen (Lumite, Gainesville, Ga.). Twenty-six plants grown in 15 x $18-\mathrm{cm}$ (2.2 liter) plastic pots were arranged within each cage in two parallel rows spaced $2.3 \mathrm{~m}$ between rows and 0.5 $\mathrm{m}$ within rows. The proportion of healthy target plants and inoculum plants varied with each test. Cages were sealed at the start of each test and opened when the infected plants were counted. Plants were watered by drip irrigation.

The first of the two field experiment series consisted of three tests designed to compare the spread of WMV from HBJ and AR HBJ inoculum plants to the target plants of the same genotype.

Two cages, one with HBJ and one with AR HBJ, were used in each of three replications. One virus source plant of each line in an individual cage $(23 \times 23 \times 30 \mathrm{~cm})$ was infested with 300 slate melon aphids for $2 \mathrm{~h}$, then removed from the cage, and placed as the seventh plant among 13 target plants in each row of their respective cages. Plants having mosaic symptoms were counted 19 days later.

The above procedures were repeated in the next two tests with minor changes. In the second test, there were only 18 target plants per cage. Each virus source plant was infested with 1000 melon aphids of all stages of growth rather than slate melon aphids only. The relative number of melon aphids per leaf at the end of the second and third tests was estimated by counting the melon aphids on the fourth or fifth leaf of 10 randomly selected plants from each cage.

The second series of field cage tests was designed to compare the spread of WMV from either HBJ or AR HBJ virus source plants to either healthy HBJ or AR HBJ target plants in separate cages, or an alternating mixture of healthy HBJ and AR HBJ target plants. Each cage contained 24 target plants and two virus source plants arranged as in the first series of field cage tests. The virus source plants were infested with $\approx 1000$ melon aphids of all stages. All five tests were stopped after 3 weeks. Data were transformed to $\arcsin \sqrt{\mathrm{x} \%+0.1}$ (Steel and Torrie, 1960) before analysis of variance (ANOVA) with MSTAT statistical analysis program.

\section{Resistance to virus transmission}

Through a number of exploratory tests (not presented), we found that 1) complete isolation of each test plant was not necessary for the precision needed to reach our objectives; 2) data from many test plants are needed to detect significant differences in resistance to virus transmission; 3) infection increased linearly with increased number of viruliferous melon aphids per plant; and 4) the maximum number of viruliferous melon aphids per plant must be more than 30 . Differences in resistance to 
virus transmission were found among melon aphid-resistant breeding 1 lines. Based on these findings, three series of tests were conducted to quantify the resistance to virus transmission among the melon aphid-resistant breeding lines.

Number of viruliferous melon aphids per plant. Eleven tests were conducted in the first greenhouse series using 5, 10, 20, 40 , or 80 viruliferous melon aphids/plant. In the first two tests, 28 plants each of AR HBJ and HBJ were infested with each viruliferous melon aphid count. In the remaining nine tests, three AR 5 sib-lines (18155, 18143, and 18169) were tested. Treatment combinations consisted of 24 to 40 plants treated with various counts of viruliferous melon aphids. Summed across the number of viruliferous melon aphids per plant, 599 plants of 18143 , 560, of 18155 , and 460 plants of 18169 were tested. Probit analyses (Finney, 1952) of the combined data of each sib-line were done with SAS/STAT Probit procedure with $\log$ option (SAS Inst., Cary, N.C.). Probabilities of single-aphid transmission, where probability of single-aphid transmission $=$ $1-(1-\mathrm{x} / \mathrm{n})^{1 / \mathrm{vma}}$, were calculated by the method of Swallow (1985), where $\mathrm{x}=$ number of infected plants, $\mathrm{n}=$ number of plants tested, and vma = number of viruliferous aphids per plant. A value of 0.001 was used when $0 \%$ infection occurred and 0.999 with $100 \%$ infection. Probability of a single-aphid transmission was calculated for each viruliferous melon aphid per plant for each line. Thus, we have three probability estimates of a single-aphid transmission (test repeated three times) for each number of viruliferous melon aphids per plant and 15 probability estimates of a single-aphid transmission for each sibline. With these 15 probability estimates, the mean, the standard error, and the $95 \%$ confidence interval were calculated for the three AR 5 sib-lines and for each of the susceptible 'PMR 45' controls.

In the second greenhouse test series, WMR 29, AR TM, AR 5 , and 18236 were compared with susceptible 'PMR 45' at 5, 10, 20, 40, and 80 viruliferous melon aphids per plant. WMR 29 is a papaya ringspot virus, watermelon strain-resistant, (PRV = WMV 1; Purcifull et al., 1984) release (Bohn et al., 1980). Progeny 18236 is a honey bee-pollinated mass increase of AR 5 , done in a screen cage, that responded differently to different counts of viruliferous melon aphids per plant in an exploratory test. This series consisted of two tests that were replicated in time and space (two blocks each time). The first test was conducted four times from Sept. through Nov. 1985; the second test, four times from Feb. through Mar. 1986. Mean greenhouse temperatures ranged from $27.5 \mathrm{C}$ (Sept.) to $21.8 \mathrm{C}$ (Nov.) during the first test and from 23.3C (Feb.) to 22.3C (Mar.) in the second test.

Two redwood greenhouse flats $(46 \times 46 \times 8 \mathrm{~cm}) \quad(\approx 112.5$ liter) positioned side-by-side and filled with soil mix constituted a plot. Nine positions at equal distances were marked in each flat, and nine positions of one and six contiguous positions (two of each row) of the second were used to create a 15-hill plot in a three-row, five-column layout. Each hill consisted of four plants of a given entry spaced $6 \mathrm{~cm}$ apart in a square pattern. Thus, each plot contained 15 hills arranged in three rows of five hills each, on $\approx 14-\mathrm{cm}$ centers. The front row of each plot was planted with one of the four test lines; the middle row was noninfested 'PMR 45' control; and the back row was the viruliferous melon aphid-infested 'PMR 45' control. A set of four plots was considered a block. There were two blocks for each test.

Each hill was covered with a cage (0.95 liter) when the plants were at the one- to two-leaf stage of growth. The four plants in each hill were exposed to the same number $(5,10,20,40$, or $80)$ of viruliferous melon aphids for $18 \pm 6 \mathrm{~h}$. Infested control ('PMR 45') plants were treated in the same manner.

A constant 60 viruliferous melon aphids per plant. The third series of the greenhouse studies tested transmission of ZYMV and were similar to those in the preceding test with the following exceptions. A single viruliferous melon aphid treatment of 60/ plant, the discriminating number, was used. The plot consisted of nine hills that included two $\mathrm{F}_{1}(\mathrm{AR} H \mathrm{HBJ} \times$ 'PMR 45') families, two open-pollinated aphid-resistant 'PMR 45' (AR 45)type families, an aphid-resistant Gulfstream (AR GS)-type family, AR 5, and two hills of 'PMR 45' controls. The test had eight replications. The number of infected plants among each four-plant hill was recorded 3 weeks later and converted to percent infection. The data were transformed to $\operatorname{arcsim} \sqrt{\mathbf{x} \%}$ (Steel and Torrie, 1960) before ANOVA.

Three more tests with the same design and-eight replications were conducted. Six melon aphid-resistant genotypes were compared among themselves or with the standard susceptible and resistant controls in each test. The remaining experimental unit consisted of noninfested 'PMR 45' control plants. In one test, three of the melon aphid-resistant genotypes were sib-pollinated AR TM families, three were $\mathrm{F}_{1}(\mathrm{AR} \mathrm{TM} \times$ 'PMR 45') families, and AR 5. In the other two tests, test entries were open-pollinated AR 5 families.

\section{Results}

\section{Field cage virus transmission tests}

In the first series of tests, the incidence of WMV infection in HBJ target plants from melon aphid-infested and WMV-infected HBJ virus source plants was significantly higher than in AR HBJ target plants from comparable AR HBJ inoculum plants for tests 1 and 2 but not for test 3 (Table 1). The counts of melon aphids in the second and third tests of this series on AR HBJ were high, but they were about one-third of those on HBJ plants (Table 1).

Table 1. Melon aphid transmission of WMV from melon aphid-susceptible HBJ and resistant AR HBJ inoculum sources to the target plants ${ }^{\mathrm{z}}$ of the same genotype.

\begin{tabular}{|c|c|c|c|c|}
\hline $\begin{array}{l}\text { Target } \\
\text { plant }\end{array}$ & $\begin{array}{l}\text { Inoculum } \\
\text { plant }\end{array}$ & $\begin{array}{l}\text { No. } \\
\text { plants }\end{array}$ & $\begin{array}{c}\text { Infected } \\
(\%)\end{array}$ & $\begin{array}{c}\text { No. aphids/ } \\
\text { leafy }\end{array}$ \\
\hline \multicolumn{5}{|c|}{ Test 1} \\
\hline HBJ & HBJ & 78 & $31 \pm 4.48^{x *}$ & --.w \\
\hline AR HBJ & AR HBJ & 78 & 0 & --- \\
\hline \multicolumn{5}{|c|}{ Test 2} \\
\hline HBJ & HBJ & 54 & $86 \pm 3.40^{* *}$ & 1687 \\
\hline AR HBJ & AR HBJ & 54 & 12 & 502 \\
\hline \multicolumn{5}{|c|}{ Test 3} \\
\hline HBJ & HBJ & 78 & $87 \pm 10.24^{\mathrm{NS}}$ & 921 \\
\hline AR HBJ & AR HBJ & 78 & 16 & 355 \\
\hline
\end{tabular}

zTest 1 started with 300 alatae/inoculum source plant. Tests 2 and 3 started with $\approx 1000$ aphids of all ages per inoculum source plant. Data are means of three replications. Tests were conducted in field cages at Riverside, Calif.

yCount at the termination of the test; 17 to 19 days after the start of an experiment.

${ }^{x}$ Retransformed mean \pm experiment-wise SE of the mean. Data transformed to arcsin $\sqrt{x \%+0.1}$ for ANOVA.

Ns, $*, * *$ Nonsignificant or significant at $P=0.05$ or 0.01 , respectively. wNot counted, all test plants had been colonized by the termination of the test. 
In the second series of field cage tests. the spread of WMV from either HBJ or AR HBJ virus source plants by melon aphid to HBJ and AR HBJ was equal (Table 2). Combined across the two source plant treatments, incidence of infection in HBJ was 97.9\%, which was about three times higher than in AR HBJ (26.7\% infected). When equal numbers of HBJ and AR HBJ were mixed as target plants in the same cage, incidence of WMV infection was intermediate to their infection frequencies in separate cages $(69.4 \%)$. Mean percent infection \pm treatmentwise error of AR HBJ was $27.5 \pm 3.96$ when it was the sole target plant and $39.9 \pm 10.26$ when it was in the AR HBJ + HBJ mixture. The higher percent infection of AR HBJ in the AR HBJ + HBJ mixture was not significantly greater than when AR HBJ was the sole target plant. Means \pm treatment-wise errors of HBJ were $92.6 \pm 3.15$ when it was the sole target plant and $95.8 \pm 1.69$ when it was in the AR HBJ + HBJ mixture. The mean aphid count per sample leaf of the target plants was lowest on AR HBJ, highest on HBJ, and intermediate on the AR HBJ + HBJ mixture when AR HBJ were the inoculum plants. The counts did not differ significantly when HBJ were the inoculum plants (Table 2).

\section{Resistance to virus transmission}

Number of viruliferous melon aphids per plant. The effective number of viruliferous melon aphids per plant to infect $50 \%$ of the test plants $\left(\mathrm{EN}_{50}\right)$ for $\mathrm{HBJ}$ was 5.49, about one-eleventh that for AR HBJ (Table 3). Small Chi-square values for AR HBJ $(P$ $\left.>x^{2}=0.91\right)$ and $\operatorname{HBJ}\left(P>x^{2}=0.704\right)$ (Table 3$)$ indicate satisfactory agreement between regression line and observed data. Tests of resistance to virus transmission in three sib-lines of AR 5 at a similar range of viruliferous melon aphids per plant could not be analyzed using the Probit method because of the low infection rate. Because all three of these tests were conducted in distinct sets, Swallow's (1985) group testing was applied. All three AR 5 sib-lines had high levels of resistance to transmission and were significantly different from the susceptible controls (Table 4). AR 5 sib-line 18143 showed significantly less resistance to virus transmission than the other two because its confidence limit of the probability of a single-aphid transmission mean did not overlap with those of the other two. How-

Table 2. Melon aphid transmission of WMV from melon aphid-resistant AR HBJ or susceptible HBJ inoculum plants to aphid-resistant AR HBJ or aphid susceptible HBJ target plants. ${ }^{2}$

\begin{tabular}{lcc}
\hline $\begin{array}{l}\text { Target } \\
\text { plants }\end{array}$ & $\begin{array}{c}\text { Infected plants } \\
(\%)\end{array}$ & $\begin{array}{c}\text { No. aphids/ } \\
\text { Ieaf }^{*}\end{array}$ \\
\hline & AR HBJ inoculum plant & \\
AR HBJ & $24.2 \mathrm{a}$ & $1825 \mathrm{c}$ \\
AR HBJ + HBJ & $67.5 \mathrm{~b}$ & $2840 \mathrm{ac}$ \\
HBJ & $97.1 \mathrm{c}$ & $3673 \mathrm{a}$ \\
& HBJ inoculum plants & \\
AR HBJ & $29.1 \mathrm{a}$ & $2207 \mathrm{bc}$ \\
AR HBJ + HBJ & $71.2 \mathrm{~b}$ & $3096 \mathrm{ab}$ \\
HBJ & $98.7 \mathrm{c}$ & $2979 \mathrm{ab}$ \\
\hline
\end{tabular}

${ }^{2}$ Data are means of 224 plants/replicate, five replications over time. Two inoculum plants per test cage, with $\approx 1000$ aphids of all ages per inoculum plant. Test conducted in field cages at Riverside, Calif. 'Data transformed to arcsin $\sqrt{\mathrm{x}+0.1 \%}$ for ANOVA. Mean separation among all treatments within a column by Duncan's multiple range test; $P=0.01$.

'Mean separation among all treatments within a column by Duncan's multiple range test, $P=0.05$. Aphid count at the termination of the experiment.
Table 3. Number of viruliferous aphids per plant required to infect $50 \%$ of the plants $\left(\mathrm{EN}_{50}\right)$ of melon aphid-resistant $\mathrm{AR} \mathrm{HBJ}$ and susceptible HBJ with WMV. Tested by Probit analysis ${ }^{z}$ of a multiple-level viruliferous melon aphid test $(5,10,20,40$, and 80 aphids/ plant). ${ }^{\mathrm{y}}$

\begin{tabular}{lccccc}
\hline \hline Entry & $\chi^{2}$ & $\begin{array}{c}\text { Intercept } \\
( \pm \mathrm{SE})\end{array}$ & $\begin{array}{c}\text { Slope } \\
( \pm \mathrm{SE})\end{array}$ & EN $_{50}$ & $\begin{array}{c}\text { Confidence } \\
\text { interval }\end{array}$ \\
\hline AR HBJ & 0.534 & $-2.71 \pm 0.33$ & $1.52 \pm 0.22$ & 61.0 & $45.3-95.1$ \\
HBJ & 1.405 & $-1.21 \pm 0.29$ & $1.64 \pm 0.24$ & 5.49 & $3.4-7.4$ \\
\hline
\end{tabular}

${ }^{2}$ SAS/STAT Probit procedure with log option. Test conducted in a greenhouse at Riverside, Calif.

yata from 56 plants tested at each level.

Table 4. The probability of a single melon aphid transmitting WMV to three melon aphid-resistant AR 5 sib-lines (18143, 18155, and $18169)$ and the aphid-susceptible 'PMR $45^{\prime}$ control.

\begin{tabular}{|c|c|c|c|c|}
\hline \multirow[b]{3}{*}{ Entry } & \multirow{2}{*}{\multicolumn{2}{|c|}{ No. plants }} & \multicolumn{2}{|c|}{ Probability of transmission ${ }^{z}$} \\
\hline & & & & $95 \%$ Confidence \\
\hline & Tested & Infected & Mean $\pm S E^{y}$ & interval \\
\hline 18143 & 558 & 140 & $\begin{array}{l}\text { Set } 1 \\
0.016 \pm 0.020\end{array}$ & $0.004-0.027$ \\
\hline PMR 45 & 557 & 397 & $\begin{array}{l}0.081 \pm 0.028 \\
\text { Set } 2\end{array}$ & $0.065-0.096$ \\
\hline $\begin{array}{l}18155 \\
\text { PMR } 45\end{array}$ & $\begin{array}{l}553 \\
560\end{array}$ & $\begin{array}{r}50 \\
421\end{array}$ & $\begin{array}{l}0.003 \pm 0.003 \\
0.090 \pm 0.035\end{array}$ & $\begin{array}{l}0.002-0.005 \\
0.070-0.110\end{array}$ \\
\hline $\begin{array}{l}18169 \\
\text { PMR } 45\end{array}$ & $\begin{array}{l}460 \\
456\end{array}$ & $\begin{array}{r}12 \\
276\end{array}$ & $\begin{array}{l}\text { Set 3 } \\
0.002 \pm 0.003 \\
0.050 \pm 0.033\end{array}$ & $\begin{array}{l}0.0003-0.003 \\
0.0320-0.068\end{array}$ \\
\hline
\end{tabular}

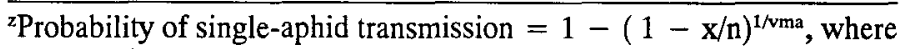
$\mathrm{x}=$ number of infected plants, $\mathrm{n}=$ number of plants tested, $\mathrm{vma}=$ number of viruliferous aphids used (Swallow, 1985).

'Means at VMA levels of $5,10,20,40$, and 80 repeated three times per set. Tests conducted in a greenhouse at Riverside, Calif.

Table 5. Probit analysis ${ }^{z}$ estimates of the number of viruliferous melon aphids needed to infect $50 \%$ of the plants $\left(\mathrm{EN}_{50}\right)$ of melon aphidsusceptible 'PMR 45' and WMR 29, and resistant AR TM and two AR 5 sib-lines (18143 and 18236) with ZYMV.

\begin{tabular}{|c|c|c|c|c|c|c|}
\hline \multirow[b]{3}{*}{ Entry } & \multicolumn{4}{|c|}{ Year } & \multirow{3}{*}{\multicolumn{2}{|c|}{ 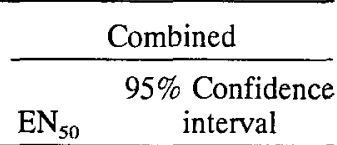 }} \\
\hline & \multicolumn{2}{|c|}{1985} & \multicolumn{2}{|c|}{1986} & & \\
\hline & $\mathrm{n}^{\mathrm{y}}$ & $\mathrm{EN}_{50}$ & $n^{y}$ & $\mathrm{EN}_{50}$ & & \\
\hline PMR 45 & 128 & 8.9 & 128 & 21.2 & 13.5 & $12.0-15.2$ \\
\hline WMR 29 & 32 & 10.9 & 32 & 20.3 & 15.6 & $12.5-19.0$ \\
\hline AR TM & 32 & 113 & 32 & 125 & 131 & $60.9-2897$ \\
\hline 18143 & 28 & 86 & 32 & $-x^{x}$ & 194 & $112-611$ \\
\hline 18236 & 32 & 180 & 32 & 410 & 254 & $137-1529$ \\
\hline
\end{tabular}

${ }^{z}$ SAS/STAT Probit procedure with log option.

y Number of plants used for each viruliferous melon aphid count $(5$, $10,20,40$, and 80 /plant) in the four tests conducted in a greenhouse at Riverside, Calif.

${ }^{\times}$No infection occurred with $5,10,20$, and 40 viruliferous melon aphids.

ever, the probability of a single-aphid transmission for one of the controls $(P=0.05$, Set 3$)$ was significantly less than that of the other two controls $(P=0.08$ and 0.09$)$.

The second series of greenhouse tests gave $\mathrm{EN}_{50}$ values for 'PMR 45' (13.5) and WMR 29 (15.6) (Table 5) that were similar to that for HBJ (5.5) in the preceding series (Table 3). The $\mathrm{EN}_{\mathrm{s}_{0}}$ values for the combined data and all three AR lines (AR TM and two AR 5 sib-lines) were eight to 19 times higher than those of susceptible 'PMR 45' and WMR 29. However, the 
results were extremelv variable. In one test, no infection was noted among the 32 plants tested at viruliferous melon aphid counts of 5, 10, 20, and 40 with AR 5 sib-line 18143. The extreme variability was reflected in the wide range of the confidence intervals of the melon aphid-resistant lines. The. $95 \%$ confidence interval ranged from 60.9 to 2897 for AR TM (Table 5). To more accurately estimate $\mathrm{EN}_{50}$ values, the number of viruliferous melon aphids per plant or the number of test plants at each count of viruliferous melon aphids per plant must be increased far beyond practicality (Bliss, 1935). Thus, an alternative assay was sought.

A constant 60 viruliferous melon aphids per plant. In subsequent tests, we chose to infest melon aphid-resistant plants with 60 viruliferous melon aphids per plant because it yielded a reliable $\mathrm{EN}_{50}$ value for $\mathrm{AR}$ HBJ and, based on preliminary data (not shown), would permit us to differentiate melon aphid resistant lines of different $\mathrm{EN}_{50}$ values on the basis of percent infection, using groups of four tests plants as an experimental unit.

In the third series of greenhouse tests, 60 viruliferous melon aphids per plant caused $93 \%$ infection of 'PMR 45' with ZYMV (Table 6). Six (results from two AR 45 sib-lines and two $F_{1}$ were combined) of the seven melon aphid-resistant lines were similar for incidence of ZYMV infection and significantly fewer plants were infected than for 'PMR 45'. The melon aphid-resistant line AR 5 (18145) had a significantly lower incidence of infection than 'PMR 45' or the other six melon aphid-resistant lines. The combined percent infection $(29 \%)$ of two $F_{1}(A R$ HBJ $x$ 'PMR 45') lines was lower than the midparent value of $54.5 \%$.

In the succeeding tests of the third series, incidence of infection of 'PMR 45' was seven times that for the AR TM sib-lines (Table 7). Infection incidence of their $\mathrm{F}_{1}$ hybrid was $30 \%$, which was significantly different from both parents. When we compared 13 open-pollinated AR 5 sib-lines exposed to 60 viruliferous melon aphids, only one line (18136 with $14 \%$ infected plants) had significantly less resistance to ZYMV transmission than the highly resistant control AR 5, 18155 (2\% infection).

\section{Discussion}

The theoretical danger of increased virus spread by increased interplant movement caused by vector host resistance was discussed by Kennedy (1976). In the early generations of our melon aphid resistance breeding program, we noticed increased melon aphid movement (Kennedy and Kishaba, 1977). Nonetheless,

Table 6. Mean percent infection in 'PMR 45', four melon aphidresistant (AR) breeding lines, and a $F_{1}$ family from a cross of an AR HBJ with 'PMR 45' after $18 \pm 6 \mathrm{~h}$ exposure to 60 viruliferous melon aphids with ZYMV.

\begin{tabular}{lcc}
\hline \hline Entry & $\begin{array}{c}\text { No. plants } \\
\text { tested }\end{array}$ & $\begin{array}{c}\text { Mean \% plants } \\
\text { infected }\end{array}$ \\
\hline PMR 45 & 32 & $93 \mathrm{a}^{\mathbf{z}}$ \\
AR PMR 45y & 64 & $20 \mathrm{~b}$ \\
F $_{1}$ (AR HBJ x PMR 45) & 64 & $29 \mathrm{~b}$ \\
AR HBJ & 32 & $16 \mathrm{~b}$ \\
AR Gulfstream & 32 & $13 \mathrm{~b}$ \\
AR 5 (18145) & 32 & $1 \mathrm{c}$ \\
\hline
\end{tabular}

${ }^{\text {zMean separation by Duncan's multiple range test, } P=0.05 \text {. Data }}$ transformed to arcsin $\sqrt{\mathrm{x} \%}$ for ANOVA. Tests conducted in a greenhouse at Riverside, Calif.

yCombined data from two sib-lines.

${ }^{x}$ Combined data from two $F_{1}$ families.
Table 7. Mean percent infection in 'PMR 45', sib-lines of melon aphid-resistant AR Topmark, $\mathrm{F}_{1}$ (PMR $45 \times$ AR Topmark), and melon aphid-resistant AR 5 (18145) when infested with $60 \mathrm{ZYM}$ viruliferous aphids.

\begin{tabular}{lcc}
\hline \hline Entry & $\begin{array}{c}\text { No. plants } \\
\text { tested }\end{array}$ & $\begin{array}{c}\text { Mean \% plants } \\
\text { infected }\end{array}$ \\
\hline PMR 45 & 64 & $85 \mathrm{a}^{\mathbf{z}}$ \\
AR Topmark sib-lines $^{y}$ & 96 & $12 \mathrm{c}$ \\
F $_{1}$ (PMR 45 x AR Topmark) & 96 & $30 \mathrm{~b}$ \\
AR 5 & 64 & $0 \mathrm{~d}$ \\
\hline
\end{tabular}

${ }^{\text {zMean separation by Duncan's multiple range test, } P=0.05 \text {. Data }}$ transformed to arcsin $\sqrt{\mathrm{x} \%}$ for ANOVA. Tests conducted in a greenhouse at Riverside, Calif.

yCombined data from three sib-lines.

${ }^{x}$ Combined data from three $F_{1}$ families.

with the melon aphid as the vector and either a solid planting of melon aphid-resistant plants or an equal mixture of melon aphid-resistant and susceptible plants, infection was less on melon aphid-resistant plants, likely caused by resistance to virus transmission, thus negating the effects of increased melon aphid movement reported earlier. Without this added resistance to virus transmission in our melon aphid-resistant progenies, the results could have been reversed. The degree of infection $(32 \%)$ of susceptible plants in test 1 of the first series of the field cage tests seems low and likely resulted from the few introduced vectors and use of alatae. It is important to note that melon aphid-resistant plants consistently had lower percentages of infection than susceptible plants in all tests, although not significantly less in test 3 , series $1\left(\mathrm{~F}=9.62,1 \mathrm{df}, \mathrm{P}_{0.09}\right)$ (Table 1$)$. For unknown reasons, the percentage of infected plants in test 3, series 1 was more variable than in the first two tests: AR HBJ ranged from $8 \%$ to $27 \%$ and $\mathrm{HBJ}$ ranged from $65 \%$ to $100 \%$.

Interchange of melon aphid-resistant and susceptible lines as inoculum plants showed that resistance was to transmission rather than to virus acquisition and concurred with the investigation by Romanow et al. (1986) and Lecoq et al. (1979, 1980). If resistance to virus multiplication reported by Moyer et al. (1985) was present in AR HBJ, it was not reflected in our results and perhaps was masked by the high aphid population. Aphid counts seemed high, but a melon aphid resistant : melon aphid susceptible ratio of 1:3 agreed closely with ratios for previous antibiosis studies (Kishaba et al., 1976). Resistance to virus transmission was so effective that when susceptible and melon aphid-resistant target plants were alternated, nearly every susceptible target plant showed the mottle symptoms, while only about half of the resistant target plants showed symptoms. This alternate pattern of infection further supports the hypothesis of Romanow et al. (1986) that resistance is to transmission.

Probit analysis of transmission data from studies with a range of viruliferous melon aphids per plant showed that a quantitative comparison of resistance to virus transmission was possible. The $\mathrm{EN}_{50}$ for $\mathrm{AR} \mathrm{HBJ}$ was 61 viruliferous melon aphids and that of susceptible HBJ was 5 viruliferous melon aphids (Table 3). However, other melon aphid-resistant breeding lines tested possessed levels of resistance too high for the range of viruliferous melon aphids used and, consequently, the results were too variable to properly estimate $\mathrm{EN}_{50}$ with the maximum of 80 viruliferous melon aphids per plant. For Probit analysis, it was suggested that number of viruliferous melon aphids be nearly equally distributed above and below $\mathrm{EN}_{50}$ (Finney, 1952). Our projections indicated that from 137 to 1529 viruliferous melon 
aphids per plant are required to infect $50 \%$ of AR 5 sib-line 18236 (Table 5). This number of viruliferous melon aphids per plant does occur in nature (Dickson et al., 1949), but is a physically impossible number to handle under experimental conditions. Alternatively, the range of the number of viruliferous melon aphids per plant used in our studies could be used if the number of test plants at each number of viruliferous aphids is adjusted so that each number of viruliferous melon aphids per plant receives equal weight for Probit analysis (Bliss, 1935), i.e., use more test plants as predicted percent infection is less than and greater than $50 \%$. If done as recommended, a total of 225 test plants and 7400 viruliferous melon aphids would be required to complete the test.

A more expedient method to identify populations with resistance to virus transmission was found using the $\mathrm{EN}_{50}$ of $\mathrm{AR}$ HBJ. We have taken 60 viruliferous melon aphids as the discriminating number because it effectively separated populations with a $10 \%$ difference in resistance to virus transmission using 32 to 64 test plants. The selection of the discriminating number is based on many exploratory tests and the tests reported herein. By using 60 viruliferous melon aphids per plant, we approached $100 \%$ infection with the susceptible lines, while melon aphidresistant lines showed $<10 \%$ infected plants. Those with greater or lesser resistance to virus transmission than AR HBJ would assort accordingly. We do not think the fortuitous selection of 60 viruliferous aphids alone made possible the separation of a $10 \%$ difference. Undoubtedly, the use of four plants as an experimental unit reduced the variability experienced with singleplant experimental units and contributed to the efficacy of the method.

The merit of using a discriminating dose (number) rather than a multiple-dosage (numbers) assay for practical application was discussed by Roush and Miller (1986). Discriminating dosage (number) was used to select and rear pyrethroid-resistant $\mathrm{He}$ liothis armigera (Hubner) (Gunning et al., 1984); and perhaps the discriminating dose could be used to increase the level of resistance to virus transmission in breeding lines for melon aphid resistance.

Swallow (1985) and Romanow et al. (1986) described and applied the probability of a single-aphid transmission for virus transmission studies. Swallow's method has a sound mathematical basis with general application. The probability of a single-aphid transmission is most applicable and versatile for an empirical situation because it adjusts for the number of viruliferous melon aphids by giving more or less weight according to the number of aphids used. Because the probability is adjusted to a single-aphid basis, even exploratory data with a wide range in the number of viruliferous melon aphids per plant can be used for comparisons.

For our comparisons, we calculated the probability of a single-aphid transmission for each number of viruliferous melon aphids per plant for the greenhouse transmission series 1 , tests 1 and 2, comparing HBJ and AR HBJ. The average probability of a single-aphid transmission was expressed as a ratio with that of the susceptible control and compared by Probit analysis. Mean probability of a single-aphid transmission was 0.0890 for HBJ and 0.0122 for AR HBJ, a ratio of $1: 7 . \mathrm{EN}_{50}$ from Probit analysis of the same data was 5.49 viruliferous melon aphids per plant for HBJ and 61.01 for $\mathrm{AR} \mathrm{HBJ}$, a ratio of $1: 11$. In an exploratory test with five, 10 , and 30 viruliferous melon aphids per plant, the probability of a single-aphid transmission ratio was 1:4, while the Probit ratio was 1:8. In both instances, the relative resistance estimate was less with probability of a singleaphid transmission. For precise comparison of the two methods, a test specifically designed for this purpose should be conducted.

Probit analysis and determination of the probability of a single-aphid transmission require many test plants. Romanow et al. (1986) used 21 to 40 plants with five viruliferous melon aphids per plant per replicate and 10 replications; this is a total of 210 to 400 plants. We used 280 plants for the Probit test. Muskmelon breeders usually do not have that many plants to work with during selection of segregating families.

If the probability of infection can be related to a standard susceptible control in each test, adjustments can be made for variation among tests and seasons. Combined use of discriminating dosage and probability of a single-aphid transmission should effectively separate progeny differences and aid selection in a breeding program for resistance to virus transmission.

That most aphid-resistant lines tested were resistant to virus transmission without being selected for resistance to virus transmission supports the hypothesis that resistance to virus transmission and resistance to the melon aphid are conditioned by the same or closely linked genes (Pitrat and Lecoq, 1982). The difference in range of resistance to virus transmission (four to 19 times higher than for 'PMR 45') and melon aphid resistance (antibiosis modality, three to six times higher than 'PMR 45') does, however, need to be explained. Differences in the genetic makeup for antibiosis in AR TM, AR HBJ, and AR 5 could be a possibility because antibiosis is considered to be multigenic (Kishaba et al., 1975), and these differences could be reflected in the wide range of resistance to virus transmission. Genetic background (i.e., modifier genes) of the recurrent parents could have a major effect on the expression of melon aphid resistance and resistance to virus transmission. Differences in resistance to virus transmission and melon aphid resistance expressed by the recurrent parents cannot explain these differences because both are equally susceptible to viruses and the melon aphid. However, vector specificity of resistance to virus transmission would suggest that the resistance to aphid and virus transmission could be one and the same.

Resistance to virus transmission described here is vector-specific; resistance is to transmission by the melon aphid, but not by Myzus persicae (Sulzer) (Lecoq et al., 1980); reported field test results reflect this fact. In North Carolina, Gray et al. (1986) showed reduction in infected aphid-resistant-related plants in a spring planting but not in a summer planting. The difference between these two plantings could have been due to changes in virus sources and vector species. Reduction was measurable in France at certain times of the year when the melon aphid was the primary vector. In our breeding plots in the Imperial Valley of California, melon aphid resistance has not reduced infection because the primary vector species is M. persicae (Wyman et al., 1979). Perhaps if our field cage tests were of longer duration, the percentage of reduction of infection would have been less. However, a grower would control the aphid population before it approached 2000/leaf. Resistance to virus transmission coupled with melon aphid resistance and resistance to virus multiplication could delay virus spread sufficiently to facilitate integration of biological control of pests in an area-wide integrated pest management program. In that situation intercrop movement of vectors would be considered and suppression of potential vectors in a reproductive host crop with plant resistance would play an important role. 


\section{Literature Cited}

Bliss, C.I. 1935. The calculation of the dosage-mortality curve. Ann. Applied Biol. 22:134-167.

Bohn, G. W., A.N. Kishaba, and J.D. McCreight. 1980. WMR 29 muskmelon breeding line. HortScience 15:539-540.

Bohn, G.W., A.N. Kishaba, J.A. Principe, and H.H. Toba. 1973. Tolerance to melon aphid in Cucumis melo L. J. Amer. Soc. Hort. Sci. 98:37-40.

Bohn, G. W., A.N. Kishaba, and H.H. Toba. 1972. Mechanisms of resistance to melon aphid in a muskmelon line. HortScience 7:281282.

Coudriet, D.L. 1962. Efficiency of various insects as vectors of cucumber mosaic and watermelon mosaic viruses in cantaloupe. J. Econ. Entomol. 55:519-520.

Demski, J.W. 1968. Local lesion reactions of Chenopodium species to watermelon mosaic virus 2. Phytopathology 58: 1196-1197.

Dickson, R. C., J.E. Swift, L.D. Anderson, and J.T. Middleton. 1949. Insect vectors of cantaloupe mosaic in California desert valleys. J. Econ. Entomol. 42:770-774.

Dodds, J. A., J.G. Lee, S.T. Nameth, and F.F. Laemmlen. 1983. Aphid- and whitefly-transmitted viruses in Imperical County, California. Phytopathology 74:221-225.

Finney, D.J. 1952. Probit analysis. Cambridge Univ. Press, London.

Foster, R.E. 1963. Glabrous, a new seedling marker in muskmelon. J. Hered. 54:113-115.

Gray, S. M., J.W. Moyer, G.G. Kennedy, and C.L. Campbell. 1986. Virus suppression and aphid resistance effects on spatial and temporal spread of watermelon mosaic virus 2. Phytopathology 76:1254 1259 .

Gunning, R, V., C.S. Easton, L.R. Greenup, and V.E. Edge. 1984. Pyrethroid resistance in Heliothis armiger (Hubner) (Lepidoptera: Noctuidae) in Australia. J. Econ. Entomol. 77:1283-1287.

Kennedy, G.G. 1976. Host plant resistance and the spread of plant viruses. Environ. Entomol. 5:827-832.

Kennedy, G.G. and A.N. Kishaba. 1977. Response of slate melon aphids to resistant and susceptible muskmelon lines. J. Econ. Entomol. 70:407-410.

Kennedy, G. G., A.N, Kishaba, and G.W. Bohn. 1975. Response of several pest species to Cucumis melo L. lines resistant to Aphis gossypii Glover. Environ. Entomol. 4:653-657.

Kennedy, G. G., D.L. McLean, and M.G. Kinsey. 1978. Probing behavior of Aphis gossypii Glover on resistant and susceptible muskmelon. J. Econ. Entomol. 71:13-16.

Kishaba, A. N., G.W. Bohn, and H.H. Toba. 1971. Resistance to Aphis gossypii in muskmelon. J. Econ. Entomol. 64:935-937.

Kishaba, A. N., G.W. Bohn, and H.H. Toba. 1976. Genetic aspects of antibiosis to Aphis gossypii on Cucumis melo from India. J. Amer. Soc. Hort. Sci. 101:557-561.

Kogan, M. and E.F. Ortman. 1978. Antixenosis-A new term proposed to define Painter's "non-preference" modality of resistance. Bul. Entomol. Soc. Amer. 24:175-176.

Lecoq, H., S. Cohen, M. Pitrat, and G. Labonne. 1979. Resistance to cucumber mosiac virus transmission by aphids in Cucumis melo. Phytopathology 69:1223-1225.

Lecoq, H., G. Labonne, and M. Pitrat. 1980. Specificity of resistance to virus transmission by aphids in Cucumis melo. Ann. Phytopathol. 12:139-144.

McCreight, J. D., A.N. Kishaba, and G.W. Bohn. 1984. AR Hale's Best Jumbo, AR 5, and AR Topmark: Melon aphid-resistant muskmelon breeding lines. HortScience 19:309-310.

Metcalf, C. L., W .P. Flint, and R.L. Metcalf. 1962. Destructive and useful insects. McGraw-Hill, New York.

Milne, K. S., R.G. Grogan, and K.A. Kimble. 1969. Identification of viruses infecting cucurbits in California. Phytopathology 59:819828 .

Moyer, J. W., G.G. Kennedy, and L.R. Romanow. 1985. Resistance to watermelon mosaic virus 2 multiplication in Cucumis melo. Phytopathology 75:201-205.

Nameth, S. T., J.A. Dodds, A.O. Paulus, and A.N. Kishaba. 1985. Zucchini yellow mosaic virus associated with severe diseases of melon and watermelon in southern California desert valleys. Plant Dis. 69:785-788.

Pitrat, M. and H. Lecoq. 1980. Inheritance of resistance to cucumber mosaic virus transmission by Aphis gossypii in Cucumis melo. Phytopathology 70:958-961.

Pitrat, M. and H. Lecoq. 1982. Relations génétiques entre les résistances par non-acceptation et par antibiose du melon à Aphis gossypii. Recherche de liaisons avec d'autres gènes. Agronomic 2:503508.

Purcifull, D., J. Edwardson, E. Hiebert, and D. Gonsalves. 1984. Papaya ringspot virus. Cmwlth. Agr. Bur./Assn. Applied Biologists Descriptions of Plant Viruses July 1984. no. 292 (no. 84 revised).

Romanow, L. R., J.W. Moyer, and G.G. Kennedy. 1986. Alteration of efficiencies of acquisition and inoculation of watermelon mosaic virus 2 by plants resistant to the virus and to an aphid vector. Phytopathology 76:1276-1281.

Roush, R.T. and G.L. Miller. 1986. Considerations for design of insecticide resistance monitoring programs. J. Econ. Entomol. 79:293298.

Smith, K.M. 1972. A textbook of plant virus diseases. Academic, New York.

Steel, R.G.D. and J.H. Torrie. 1960. Principles and procedures of statistics. McGraw-Hill, New York.

Swallow, W.H. 1985. Group testing for estimating infection rates and probabilities of disease transmission. Phytopathology 75:882-889.

Ward, G.M. 1973. Calcium deficiency symptoms in greenhouse cucumbers. Can. J. Plant Sci. 53:849-856.

Webb, R.E. 1965. Luffa acutangula for separation and maintenance of watermelon mosaic virus 1 free of watermelon mosaic virus 2 . Phytopathology 55:1379-1380.

Webb, R.E. and H.A. Scott. 1965. Isolation and identification of watermelon mosaic viruses 1 and 2. Phytopathology 55:895-900.

Wyman, J. A., N.C. Toscano, K. Kido, H. Johnson, and K.S. Mayberry. 1979. Effects of mulching on the spread of aphid-transmitted watermelon mosaic virus to summer squash. J. Econ. Entomol. $72: 139-143$. 